\title{
Solar Energy Development in Pakistan: Barriers and Policy Recommendations
}

\author{
Muhammad Irfan *(D), Zhen-Yu Zhao *, Munir Ahmad(D) and Marie Claire Mukeshimana \\ Beijing Key Laboratory of New Energy and Low Carbon Development, School of Economics and Management, \\ North China Electric Power University, Beijing 102206, China; munirahmad@ncepu.edu.cn (M.A.); \\ muclairese@hotmail.com (M.C.M.) \\ * Correspondence: irfan@ncepu.edu.cn (M.I.); zhaozhenyuxm@263.net (Z.-Y.Z.); \\ Tel.: +86-156-1189-7375 (M.I.); +86-10-6177-3150 (Z.-Y.Z.)
}

Received: 7 January 2019; Accepted: 19 February 2019; Published: 25 February 2019

\begin{abstract}
Energy generation is heavily dependent on fossil fuels in Pakistan. Due to the huge population and current progress in industrialization, these sources are not fulfilling the existing energy needs of the country. Meanwhile, they have adverse environmental impacts and are economically unsuitable to electrify remote areas. Consequently, there is a need to look for alternate energy sources. The aim of this paper is to find out the best renewable energy option for Pakistan. For this purpose, we have collected data for solar radiation and wind speed for a period of one year in four major cities of Pakistan. Results indicate that solar energy is the best renewable energy option for Pakistan in terms of price, life span, operation and maintenance cost. Key barriers have been identified over the whole solar energy spectrum through semi-structured interviews with industry professionals. And finally, important policy recommendations have been proposed for institutions and government to overcome these barriers and utilize maximum solar energy in the country.
\end{abstract}

Keywords: solar energy; resource potential; metrological data; barriers; policy recommendations; Pakistan

\section{Introduction}

Energy plays a key role in the development of modern economies. All human activities i.e., education, health care, agriculture and employment require energy for proper functioning. A country cannot succeed without proper utilization of energy. It is considered the main component of a country's economy [1]. Pakistan is a developing country. Due to recent development and to support its large population and industry, the country needs a huge amount of energy to keep all things on track $[2,3]$. However, there is a shortage of energy supply and the country is in its worst energy crisis. The gap between electricity demand and supply has been increased in the past few years and is highly obvious during summer season [4] which has resulted in the complete shutdown of power for 10-12 $\mathrm{h}$ in urban areas and for 16-18 $\mathrm{h}$ in rural areas [5-8].

Energy shortage problems not only affect the life of individuals but also hindering the economic development of the country. All sectors including agricultural, industrial, transport, domestic and energy generation have been affected severely due to long power outages and caused huge economic loss to the country. The current share of renewable energy is insufficient in the total energy mix of Pakistan [9]. The country fulfills its energy needs by utilizing fossil fuels [10]. Huge dependency on fossil fuels not only has a burden on the national economy but also have led to different environmental hazards like the greenhouse effect, $\mathrm{CO}_{2}$ emissions, global warming and irregular weather patterns. Moreover, natural resources are being exhausted due to overuse of fossil fuels. Hence, there is a need to develop a new energy economy. In this new economy, renewable energy sources (wind, solar and 
biomass) will be utilized to produce energy which can decrease the fossil import bill on one hand, and lessen the climatic challenges on the other hand [11].

Energy demand is increasing by more than $9 \%$ annually in Pakistan. It is expected that energy demand will increase 8-fold by 2030 and 20-fold by 2050 in Pakistan [12]. The major reason of energy crises in Pakistan is that energy structure is mainly dependent on thermal resources including coal, oil and natural gas which are expensive as well as are under huge pressure of shortage. In the recent past, the share of hydroelectricity has reduced significantly. Moreover, renewable energy sources only fulfill $0.3 \%$ of the energy needs of the country, which is almost negligible. Among different renewable energy options, solar energy has the potential to tackle all these challenges. It has emerged as the most competitively priced technology worldwide. According to the International Energy Agency, global capacity of solar PV had reached 402 gigawatts (GW) at the end of 2017. It will further expand by almost $580 \mathrm{GW}$ and lead the renewable electricity capacity growth [13]. Luckow et al. [14] found out the institutional and technical barriers associated with solar energy. The European commission carried out research programs on solar energy for almost two decades to reduce pollution and carbon emissions, ensure energy security and diversify energy mix of European countries [15].

Geographically, Pakistan lies in the sun belt and receives massive amounts of sunlight all through the year. To address the current energy issues, it is very important to exploit the existing solar energy resources. Meanwhile, public and private sector investment is very important to harness its true potential [16]. Many researchers have focused on solar energy to estimate its potential for proper utilization in the country [17]. Khalil and Zaidi [18] found out the reasons for energy crises in Pakistan. Shaikh et al. [19] stressed on the importance of solar energy as a natural asset for Pakistan. Farooq and Shakoor [5] suggested solar thermal as the best option for current energy crises in the country. Farooq and Kumar [20] assessed the technical potential to generate electricity from solar technology. Shakeel et al. [21] reported that the country has an overall solar power potential of 1600,000 MW. Mirza et al. [22] discussed the outlook and status of utilization of solar energy in Pakistan and highlighted the role of research and development organizations to develop solar energy in the country. Muneer et al. [3] described the potential applications of solar thermal i.e., solar water heaters for the textile industry. Ghafoor and Munir [6] designed an off-grid PV system for domestic users. Some researchers found challenges associated with renewable energy [23-28]. But no one has tried to compare indigenous renewable energy sources over different factors to realize the best energy choice for Pakistan.

To bridge this research gap, it is very crucial to carry out comprehensive research. This study is the first attempt to find out the best energy option for Pakistan, among many renewable energy sources. We have compared the efficiency of wind turbines and solar radiation intensity in four major cities of Pakistan. For this purpose, data was collected every month for a period of one year. The data was then analyzed by employing MAT Lab and RT Screen. The research findings indicate that solar energy is the best renewable energy option for Pakistan due to many factors such as price, operation and maintenance costs and life span. Moreover, we found the major barriers associated with solar energy in Pakistan by conducting semi-structured interviews with industry professionals. Finally, we have proposed policy recommendations for government and key stakeholders to overcome these barriers and further develop the solar power industry in Pakistan.

The paper is organized as follows, Section 2 examines the worldwide status of solar energy. Section 3 compares the solar energy utilization among Pakistan, India and China. Section 4 discusses the geography, topography and socioeconomic profile of Pakistan. The current energy scenario in Pakistan has been described in Section 5. Section 6 discusses the grid structure and situation of solar energy in Pakistan. Section 7 illustrates the methods used to conduct this research. Solar energy applications have been described in Section 8. Barriers to solar energy development have been discussed in Section 9. Section 10 is devoted to the policy recommendations for solar energy development. And finally, Section 11 concludes the study. 


\section{Worldwide Status of Solar Energy}

According to renewables global status report, the global solar photovoltaic (PV) installed capacity reached $402 \mathrm{GW}$ at the end of 2017. Up to $98 \mathrm{GW}$ were added during 2017 and the global solar PV installed capacity was $303 \mathrm{GW}$ at the end of 2016. Table 1 shows the top 10 countries with their cumulative installed solar PV capacity. It is obvious from Table 1 that $86 \%$ of the total solar PV capacity has been installed by these countries and the share of other countries in the world is only $14 \%$ [29].

Table 1. Top 10 cumulative solar PV capacity in the world 2017.

\begin{tabular}{cccc}
\hline Country & Total End-2016 & Added during 2017 & Total End-2017 \\
\hline China & 78.1 & 53.1 & 131.1 \\
United States & 40.4 & 10.6 & 51 \\
Japan & 42 & 7 & 49 \\
Germany & 40.7 & 1.7 & 42.4 \\
Italy & 19.3 & 0.4 & 19.7 \\
India & 9.2 & 9.1 & 18.3 \\
United Kingdom & 11.8 & 0.9 & 12.7 \\
France & 7.2 & 0.9 & 8 \\
Australia & 6 & 1.3 & 7.2 \\
Spain & 5.5 & 0.1 & 5.6 \\
Rest of the world & 43 & 14 & 57 \\
Total Top 10 & 260 & 85 & 345 \\
World Total & 303 & 98 & 402 \\
\hline
\end{tabular}

China, the global leader in the solar energy sector has progressed remarkably in the recent past. The country had a total installed solar PV capacity of $131.1 \mathrm{GW}$ at the end of 2017. The United States installed 51 GW of solar PV and ranks second. Similarly, Japan 49 GW, Germany 42.4 GW, Italy 19.7 GW, India 18.3 GW, United Kingdom 12.7 GW, France 8 GW, Australia 7.2 GW, and Spain 5.6 GW. Figure 1 shows the percentage share of total installed solar PV capacity in top countries of the world.

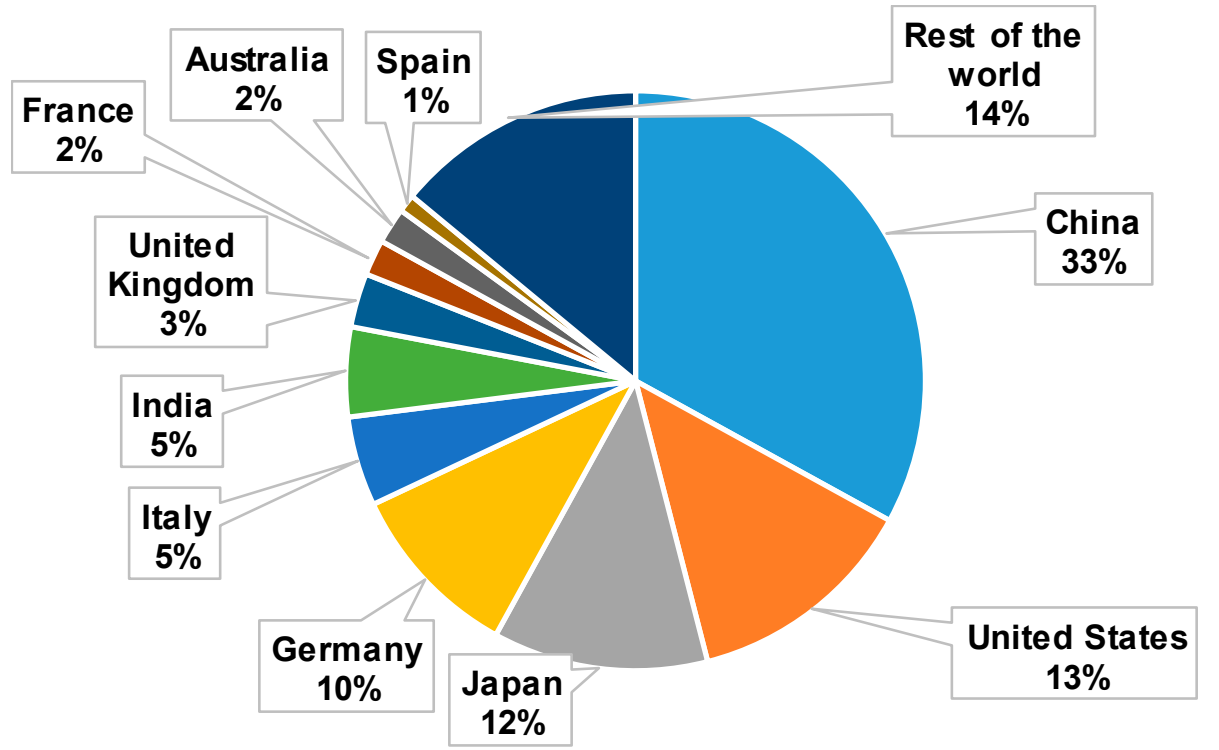

Figure 1. Percentage share of installed solar photovoltaic capacity in top countries of the world [29].

\section{Comparison of Solar Energy Utilization in Pakistan, India and China}

Fossil fuels are the main sources of energy generation in major Asian countries like Pakistan, India and China. Pakistan uses natural gas (44\%) as a major source of electricity generation. On the other hand, the major electricity generation source of India and China is Coal which accounts for $57 \%$ 
and $72 \%$ respectively [30-32]. Scarce fossil fuels are under huge pressure of shortage due to massive use. Therefore, governments in these countries are looking for clean and renewable energy sources, especially solar energy, to reduce their dependence on traditional sources of energy.

China made great progress in Solar energy generation as compared to Pakistan and India. Figure 2 shows China's quick progress on solar energy generation from 2008 to 2017. Within this period, the installed capacity increased from $113 \mathrm{MW}$ to 131,100 MW indicating marvelous growth. Pakistan and India on the other hand are far behind China in solar energy utilization. Figure 3 compares the solar energy generation between Pakistan and India from 2008 to 2017. At the end of 2017, Pakistan had an installed solar capacity of $730 \mathrm{MW}$ while India had 18,300 MW [33].

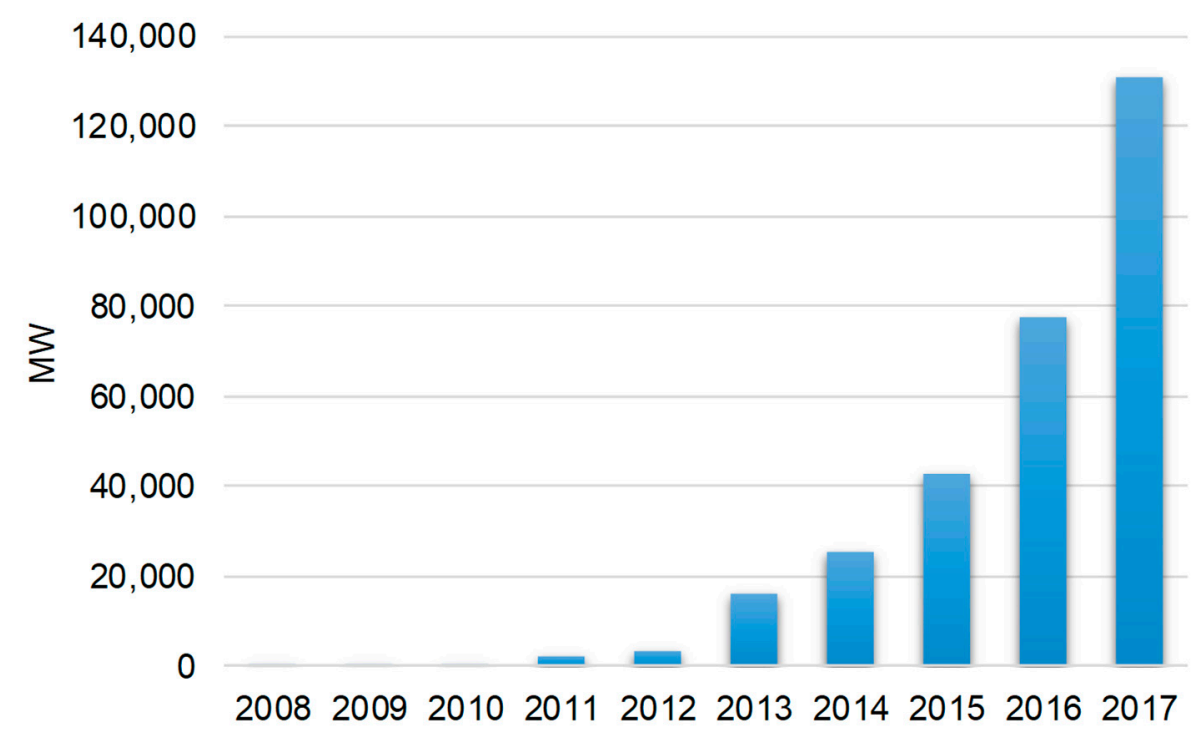

Figure 2. Solar energy generation in China.

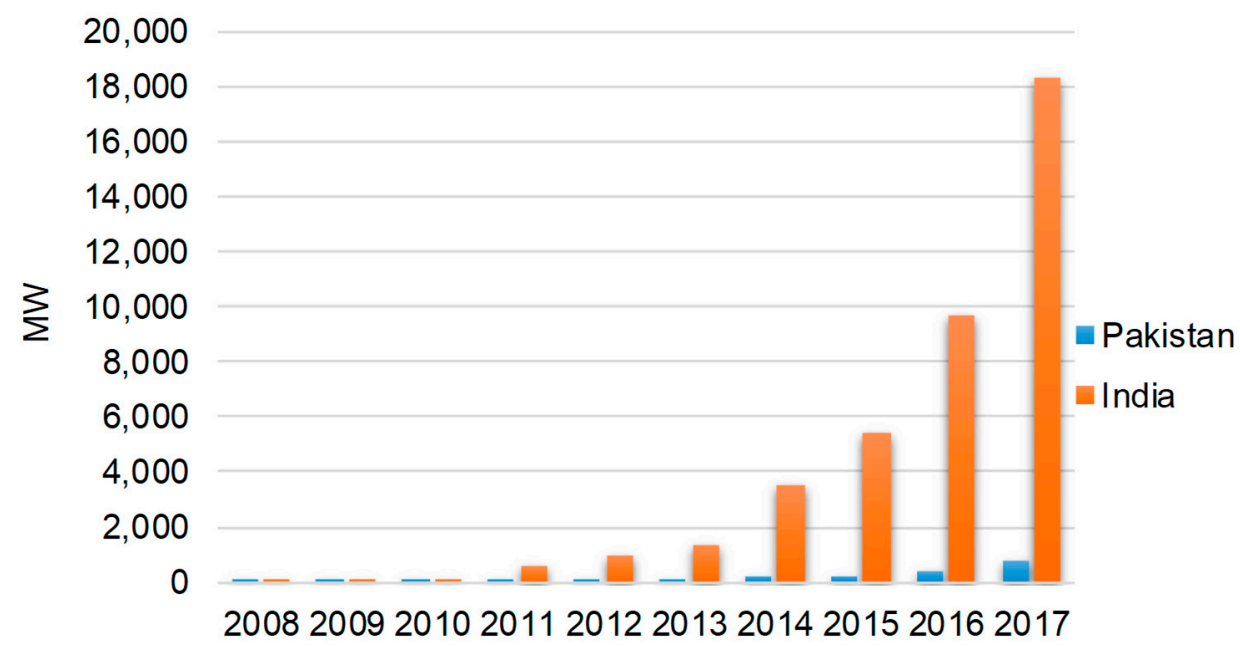

Figure 3. Comparison of solar energy generation between Pakistan and India.

\section{Geography, Topography and Socioeconomic Profile of Pakistan}

Pakistan is placed between latitude $24^{\circ}$ and $37^{\circ}$ north and longitude $62^{\circ}$ and $75^{\circ}$ degrees east. It is surrounded by 4 countries. On the north side, it shares its border with China. On the south side, there is Arabian sea. India is on the east side, Iran on the west side and Afghanistan is on the north-west side of Pakistan. Punjab, Sindh, Baluchistan, Khyber Pakhtunkhwa and Gilgit Baltistan are the five provinces of Pakistan. Many federally administered tribal areas are also located in Pakistan [22,34]. 
In Gilgit Baltistan and northern areas of Pakistan, there are some of world's largest mountain ranges i.e., Himalayas, Hindukush and Karakoram. The world's second highest mountain K-2 is also found in the Karakorum range [16]. The provinces of Punjab and Sindh consists of flat plains and five rivers which eventually join the Indus river. The Indus is the largest river of Pakistan. On the west side there is the Baluchistan Plateau which is an arid tableland surrounded by dry mountains [22,35].

Pakistan is the 6th largest country by population in the world. According to the United Nations report, the current population of Pakistan is 202,272,196. Out of a total population, 39.5 percent of the population lives in urban areas. The country has a total area of 796,096 $\mathrm{km}^{2}$ [36]. In 2018, the gross domestic product (GDP) had reached 300 billion US dollars with an annual growth rate of $5.8 \%$ GDP. In a developing country like Pakistan, the services and facilities are inadequate to address the increasing demands of population and economy for energy, resulting in increasing pressure on scarce energy resources. it is expected that the annual GDP growth rate will decrease from 5.8 to $5.4 \%$ in 2020, causing high poverty and a low standard of living in Pakistan [37]. Although, current government policies have helped in reducing poverty, a large population is still below the poverty line and living on less than 2 US dollars per day. Figure 4 compares the population in South Asian countries living below $\$ 2$ per day. It is quite interesting that Pakistan ranks 3rd in this category, while more poor live in India and Bangladesh [38].

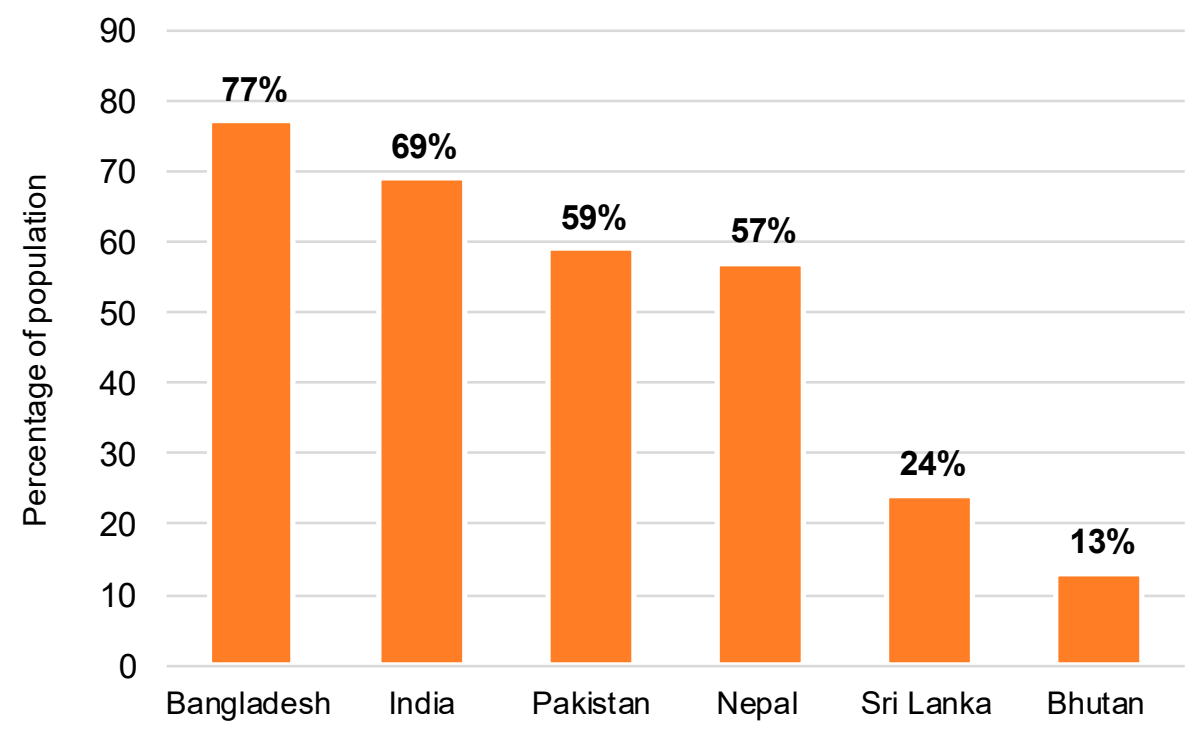

Figure 4. Percentage of population living below \$ 2 per day in South Asia [38].

\section{Current Energy Scenario in Pakistan}

Since last century, the demand for energy has increased tremendously all over the world and Pakistan is no exception. All human activities require energy for proper functioning. Pakistan is struggling with a huge energy crisis at the moment, which not only hindering the progress of country but also affecting the daily life of people. All major sectors of Pakistan i.e., agriculture, transport, industry and domestic needs a continuous supply of energy. Due to the continuous demand for energy, the gap between electricity demand and supply has increased, resulting in the depletion of energy resources [39]. Table 2 shows the electricity installed capacity from different sources in Pakistan from the period of 2012 to 2016 [4]. 
Table 2. Electricity Installed capacity by type (MW).

\begin{tabular}{cccccc}
\hline Type & $\mathbf{2 0 1 2}$ & $\mathbf{2 0 1 3}$ & $\mathbf{2 0 1 4}$ & $\mathbf{2 0 1 5}$ & $\mathbf{2 0 1 6}$ \\
\hline Nuclear & 787 & 787 & 787 & 787 & 787 \\
Renewables & 1 & 50 & 106 & 439 & 852 \\
Hydel & 6730 & 6947 & 7116 & 7116 & 7116 \\
Thermal & 15969 & 15941 & 15693 & 16619 & 16619 \\
Total & 23487 & 23725 & 23702 & 24961 & 25374 \\
\hline
\end{tabular}

Although, with the completion of recent projects the total power generation capacity of Pakistan has reached 25,374 MW. But still there is a huge electricity demand and supply gap in the country. In the past few years, this gap has been increased many times. According to the National Electric Power Regulatory Authority (NEPRA), the gap was 5298 megawatts (MW) at the end of 2016. Figure 5 shows the electricity demand and supply gap from the period of 2012 to 2016. It was expected that this gap would continue until 2018, as shown in Figure 6. Meanwhile, electricity prices have increased enormously which makes its affordability difficult for domestic and industrial consumers [40].

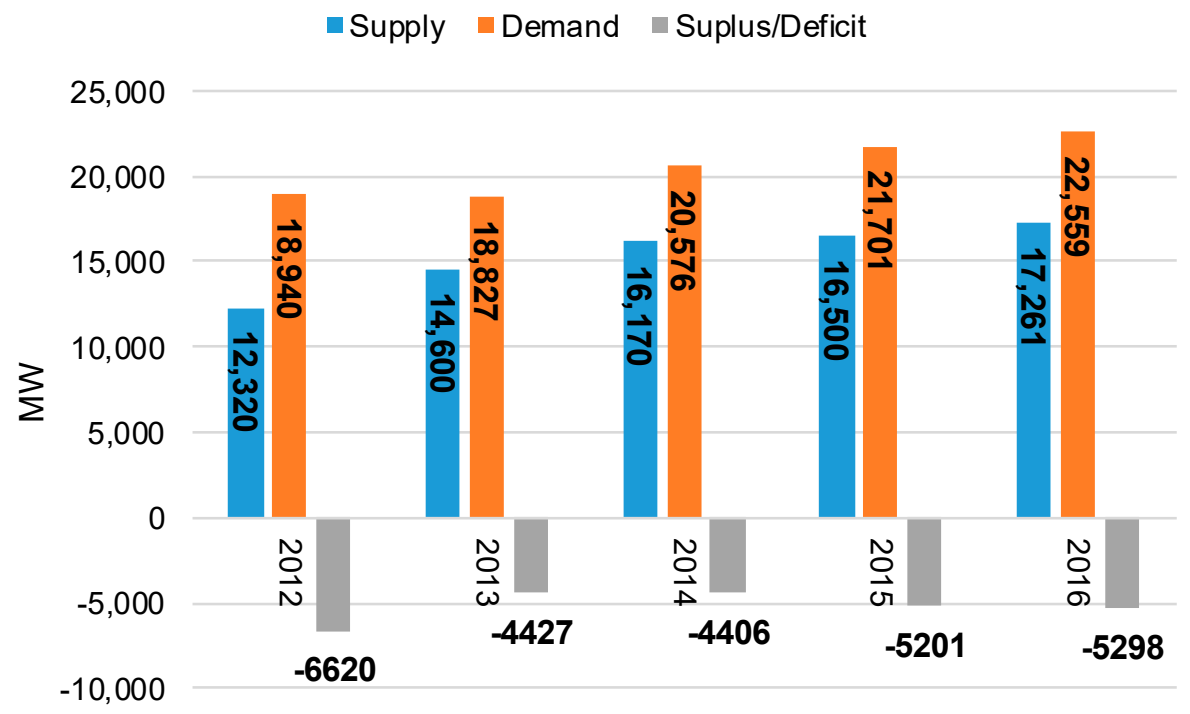

Figure 5. Electricity demand and supply during 2012-2016 [4].

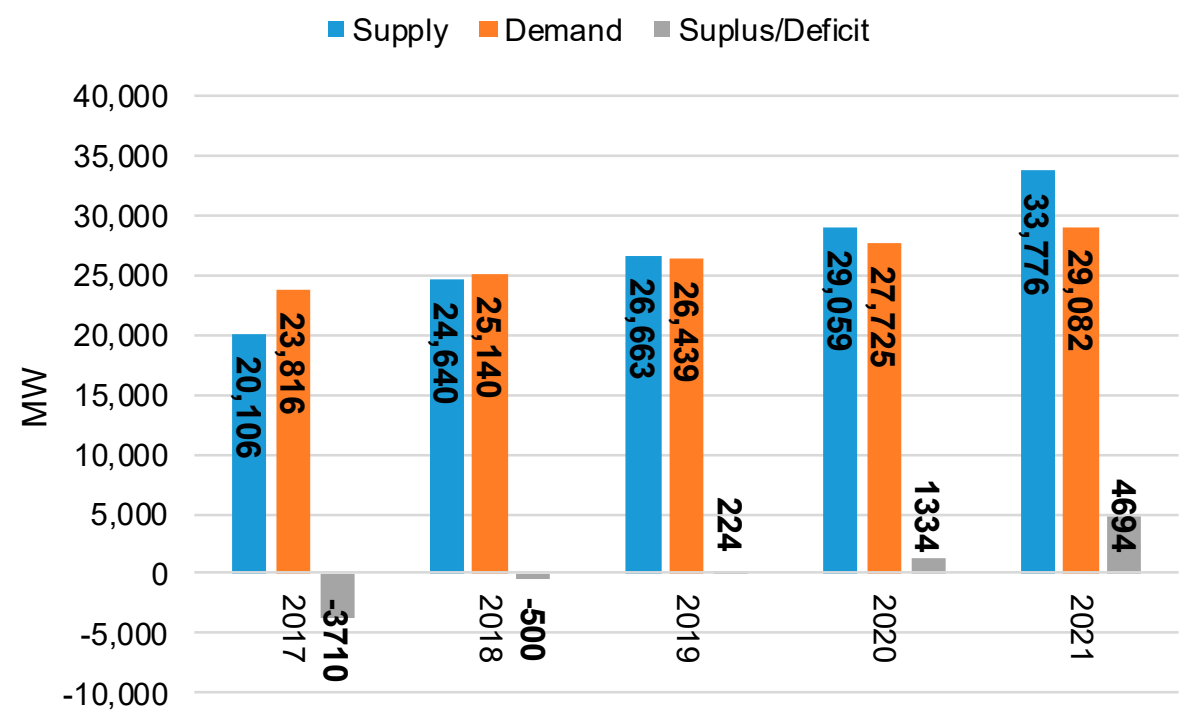

Figure 6. Projected electricity demand and supply during 2017-2021 [4]. 
The major reason for the power shortage and energy crises is that the overall mix of energy in Pakistan is extremely dependent on oil, LPG and natural gas which constitutes $78.8 \%$ of the total 70.3 million tonnes of oil equivalent (MTOE). The share of hydroelectricity in the primary energy supply of the country is $11 \%$, coal $7 \%$, Nuclear Electricity $2 \%$, Imported Electricity $0.15 \%$, LNG imported $0.67 \%$ and renewable energy $0.27 \%$, respectively, as shown in Figure 7.

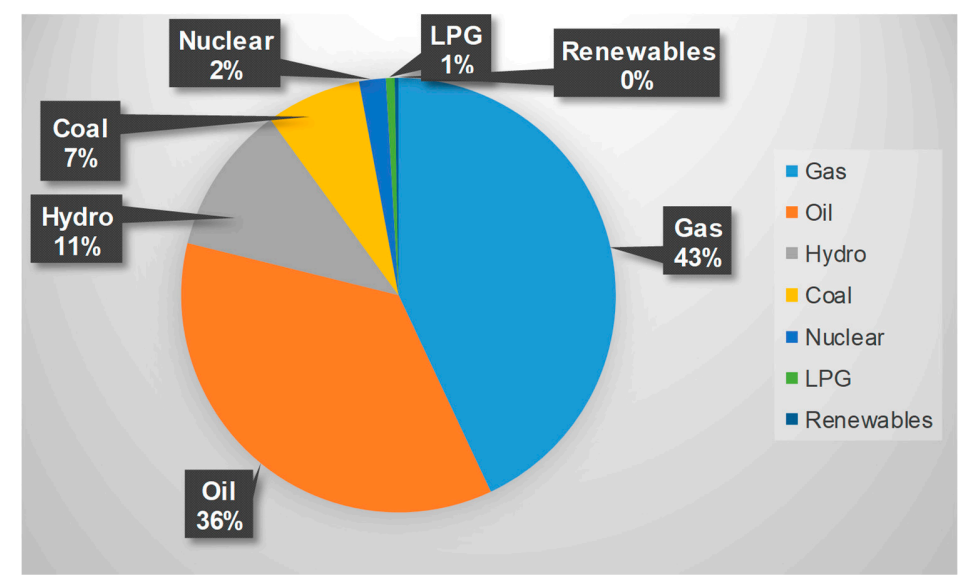

Figure 7. Primary energy supplies by source [4].

In terms of per capita energy consumption, Pakistan is still behind many south Asian countries. Table 3 shows the per capita energy consumption among different South Asian countries [13]. It is clear from the table that many South Asian countries have higher per capita energy consumption than Pakistan.

Table 3. Comparison of per capita electricity consumption of South Asian countries.

\begin{tabular}{cc}
\hline Country & Electricity Consumption/Pop (kWh/per capita) \\
\hline India & 920 \\
Sri Lanka & 630 \\
Pakistan & 500 \\
Bangladesh & 350 \\
Nepal & 170 \\
Afghanistan & 119.8 \\
\hline
\end{tabular}

51 million people still do not have access to electricity in Pakistan. This poses a great challenge to the Pakistani government and policy makers, as electricity is a necessity of modern life. During 2016, the electrification rate was $74 \%$ in Pakistan (urban population $90 \%$ and rural population $63 \%$ ). Table 4 compares the electricity access in 2016 among major South Asian countries [41].

Table 4. Electricity access in 2016 South Asia.

\begin{tabular}{ccccc}
\hline Country & $\begin{array}{c}\text { Electrification } \\
\text { Rate (\%) }\end{array}$ & $\begin{array}{c}\text { Urban Electrification } \\
\text { Rate (\%) }\end{array}$ & $\begin{array}{c}\text { Rural Electrification } \\
\text { Rate (\%) }\end{array}$ & $\begin{array}{c}\text { Population without } \\
\text { Electricity (Millions) }\end{array}$ \\
\hline India & 82 & 97 & 74 & 239 \\
Pakistan & 74 & 90 & 63 & 51 \\
Bangladesh & 75 & 90 & 67 & 41 \\
Nepal & 77 & 97 & 72 & 7 \\
Sri Lanka & 100 & 100 & 100 & 0 \\
\hline
\end{tabular}

\subsection{Meteorological Data}

The National Renewable Energy Laboratory (NREL) has developed a geospatial toolkit and solar maps to begin solar energy projects in Pakistan, as there is no authentic data available about solar 
irradiance. For this purpose, nine locations were recognized to gather reliable and accurate solar data. The Alternative Energy Development Board (AEDB) has installed weather stations at these prime locations as shown in Table 5 [42]. The World Bank has provided the required funding for the project. The World Bank will publish more accurate solar maps after observing the data taken from these weather stations for a period of two years. These maps and atlases not only help the government but also encourage commercial developers to make their policies accordingly for future projects $[43,44]$. The World Bank consistently monitored solar energy potential in different areas of Pakistan from 2000 to 2012 and published solar map Diffuse Horizontal Irradiance (DHI). According to this map, two provinces of Pakistan (Sindh, Baluchistan) have the highest solar potential. In Punjab province, some deserted areas are also ideal for solar energy. If properly harnessed, solar energy can turn out to be a sustainable solution for the energy problems of the country.

Table 5. Weather stations and their locations in Pakistan.

\begin{tabular}{cc}
\hline Weather Station & Location \\
\hline NUST & Islamabad \\
MNS campus, UET Lahore & Multan \\
NED University & Karachi \\
BUITEMS & Quetta \\
Quaid-e-Azam Solar Park & Bahawalpur \\
BUET & Khuzdar \\
Mehran University & Jamshoro \\
KSK Campus UET Lahore & Kala Shah Kaku \\
UET & Peshawar \\
\hline
\end{tabular}

\subsection{Resource assessment of Solar energy in Pakistan}

According to the Medium-Term Development Framework 2006, Pakistan plans to increase the share of renewable energy technologies (RETs) in the overall energy mix to up to $9700 \mathrm{MW}$ by the end of 2030. The country can achieve these targets and tackle energy crises if it utilizes solar energy resources in a proper and efficient way. Pakistan is located in sun belt [22]. An enormous solar potential exists in the country. Sindh, Baluchistan and some southern parts of Punjab have abundant solar energy potential. These areas receive $2 \mathrm{MWh} / \mathrm{m}^{2}$ solar irradiation and $3000 \mathrm{~h}$ of sunshine per year, which are perfect to invest in solar energy to utilize its true potential [45]. Baluchistan alone has tremendous solar energy potential. The average global insolation is $19-20 \mathrm{MJ} / \mathrm{m}^{2}$ per day and the annual mean sunshine duration is 8-8.5 h, which is perfect for the installation of solar PV and other solar energy related projects. The average temperature of the country is Celsius $26^{0}-28^{0}$. Meanwhile, the daily average solar power potential is $5.3 \mathrm{kWh} / \mathrm{m}^{2}$ [46]. The country has an overall 1,600,000 MW solar power potential [21]. If solar PV panels were installed only on a $100 \mathrm{Km}$ area of Pakistan with $14 \%$ efficiency, it could generate 30 million tons of oil equivalent (MTOE) energy in the country [47].

The distribution and transmission network of electricity in Pakistan is old and weak. Solar energy can relieve this traditional electricity network and turn out to be an alternate to traditional electricity in remote areas, where no grid electricity is available. Solar energy has already gained popularity all over the world. Current work has been going on to improve the storage capacity of the cells used in solar PV. It is also important at this point in time to make effective policies, followed by clear strategies and models to realize solar potential in the country. In this regard, Public-private partnership can turn out to be very fruitful. Different solar applications are being used in Pakistan, including solar thermal, solar PV and desalination. Meanwhile, solar thermal energy production and solar water heaters also have huge potential. Heavy reliance on fossil fuels for power generation can be minimized and the electricity demand and supply gap can be fulfilled by utilizing solar energy appliances effectively at home, public places and industries. Moreover, it will further guarantee sustainable development of the country [16]. 


\section{Research Methodology}

We employed a hybrid research methodology. First, we collected data of solar radiation intensity and wind speed every month for a period of one year in four major cities of Pakistan, namely Karachi, Lahore, Bahawalpur and Faisalabad. To ensure accurate locations for maximum solar radiation and wind speed, the NASA solar map of Pakistan and wind map of Pakistan were utilized [48,49]. Data was then calculated and plotted against the $1 \mathrm{~kW}$ solar PV and wind turbines by using MAT LAB and RT screen to compare the efficiency of solar PV and wind turbines (Figures 8-11).

We began our research from Karachi city. Located in Sindh province, the coastal city Karachi is the biggest city of Pakistan. The city is famous for Bin Qasim and Karachi sea port. Due to numerous industrial zones, the city is the economic hub and revenue engine of Pakistan. The share of this city in total GDP of the country is $25 \%$. Due to massive energy demand by domestic and industrial users, the electricity shortfall has reached $412 \mathrm{MW}$. Figure 8 compares and analyzes the monthly average electricity generation from wind turbines and solar PV in Karachi city for a period of one year. Although, good wind speed is available for a period of 5 months in Karachi to generate enough electricity, solar radiation is almost constant throughout the year, making it a better energy option than wind energy.

Lahore is the second biggest city of Pakistan after Karachi in terms of population. 90 million inhabitants live in this ancient and beautiful city. Lahore electric supply company (LESCO) is the largest electricity distribution company of this city. During the last few years, electricity demand and the supply gap has increased tremendously, due to massive population and industrial activities in the city. Consequently, LESCO is not coping with the ever-increasing demand for energy [8]. Figure 9 shows that solar energy is the best option for Lahore city, as simulation results indicate that the average monthly electricity generation is higher for solar PV than for wind turbines.

Faisalabad is famous for its textile industry and is called the Manchester of Pakistan. The textile industry accounts for $58 \%$ of the total exports of Pakistan. The city's alone contribution to total exports of the country is $40 \%$. So, Faisalabad is in crying need for energy. Long short-falls make the city more miserable. In order to find the best renewable energy source, it was revealed that solar energy gives better output in this city throughout the year, while wind energy is only appropriate in June (Figure 10).

Bahawalpur is the 11th largest city of Pakistan in terms of population with 798,509 inhabitants living in this city. The city was the former capital of Bahawalpur state. Being an industrial city, government has liberties and revolutionized key industries including poultry, cooking oil, textile, steel and flour mills. But the city is facing the worst load shedding, hindering the smooth development of industries. In terms of monthly average energy production, solar energy is the most appropriate in this city as compared to wind energy (Figure 11). Due to this fact, the Quaid-e-Azam solar park has been constructed in this city [50].

Second, we conducted semi-structured interviews with industry professionals about the different aspects of solar and wind energy to find out the best renewable energy option. These aspects are: price, average life duration, consumption of fuel, operation and maintenance costs. To compare the price of solar PV and wind turbine it was asked 'What is the cost required to generate $1 \mathrm{kWh}$ wind/solar electricity?'. Similarly, we asked 'What is the average life span of wind turbines and solar PV?' to find the life span of both technologies. Another question was included: 'What is the average maintenance cost/hour for wind power plants and solar PV?' to find out the maintenance cost. A total of 42 industry professionals were interviewed in these four cities. After considering all parameters of solar PV and wind turbines, the interviewees' responses revealed that solar energy is much cheaper than wind energy for power generation in Pakistan. As, the cost required to generate $1 \mathrm{kWh}$ energy is 65,000 Pakistani rupees (PKR) in the case of solar energy, while this is PKR 120,000 in the case of wind energy. Similarly, the average life span of solar PV is 25 years. While it is only 10-15 years for wind turbines. Solar PV do not have any maintenance cost while it is PKR 3.5/h for wind energy plants (Table 6). Finally, interviewees were asked about the barriers of solar energy development in Pakistan (see Appendix A). They revealed 
that solar energy is facing economical, technological, Information, human resource, social and policy barriers. These barriers have been described in Section 8.

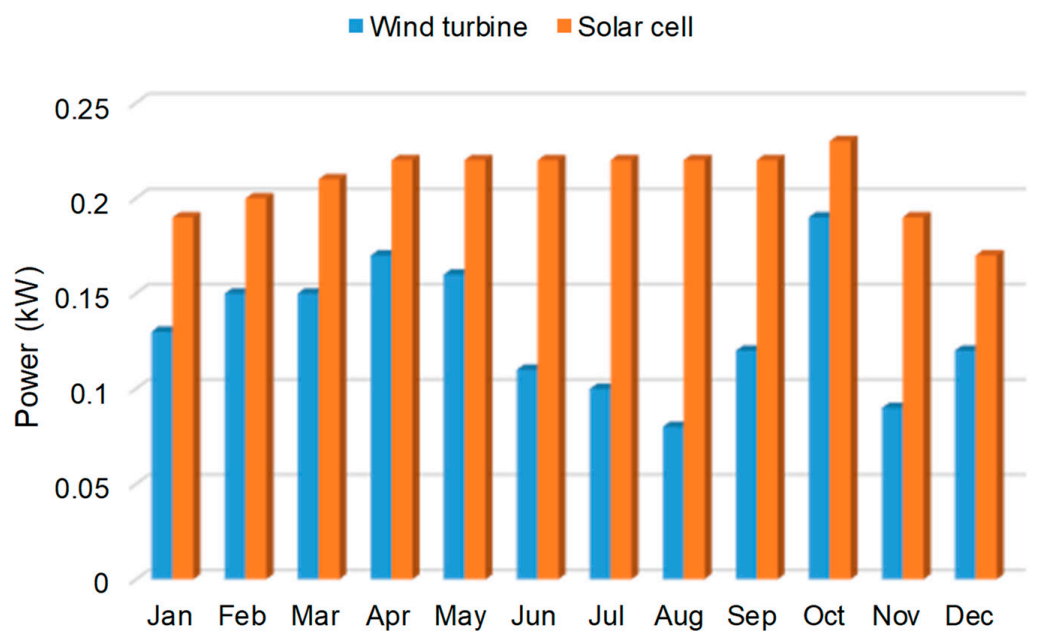

Figure 8. Comparison of electricity generation between solar PV and wind turbine at Karachi.

Wind turbine $\quad$ Solar cell

0.25

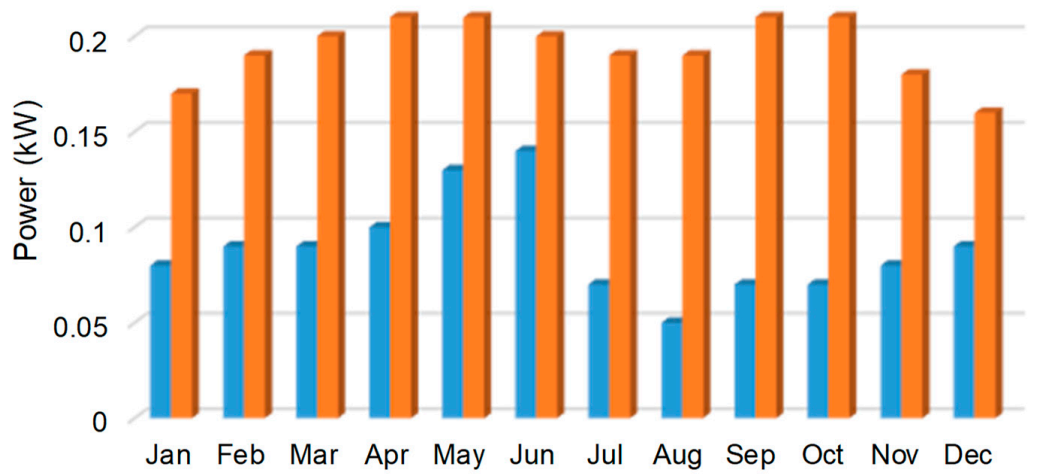

Figure 9. Comparison of electricity generation between solar PV and wind turbine at Lahore.

Wind turbine $=$ Solar cell

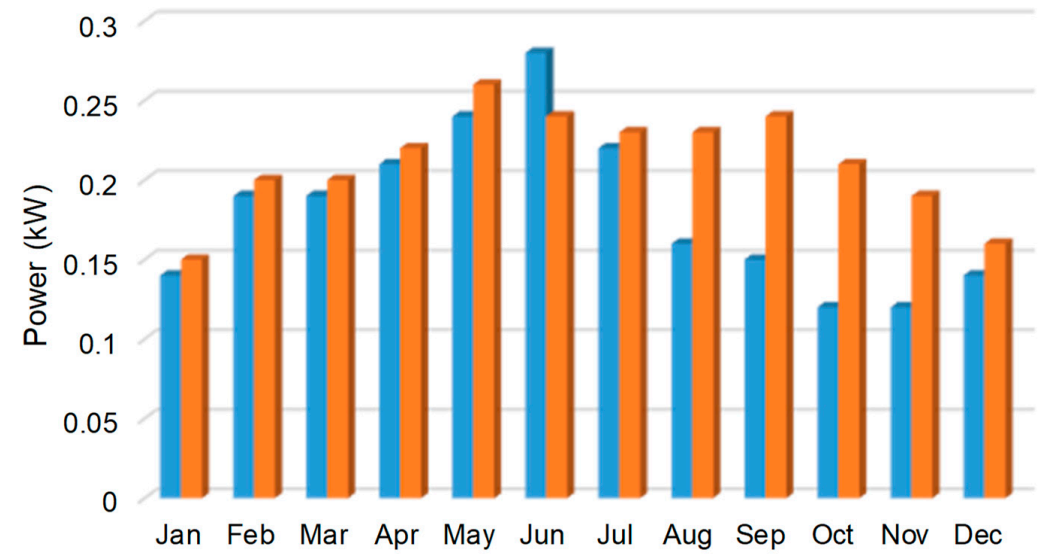

Figure 10. Comparison of electricity generation between solar PV and wind turbine at Faisalabad. 


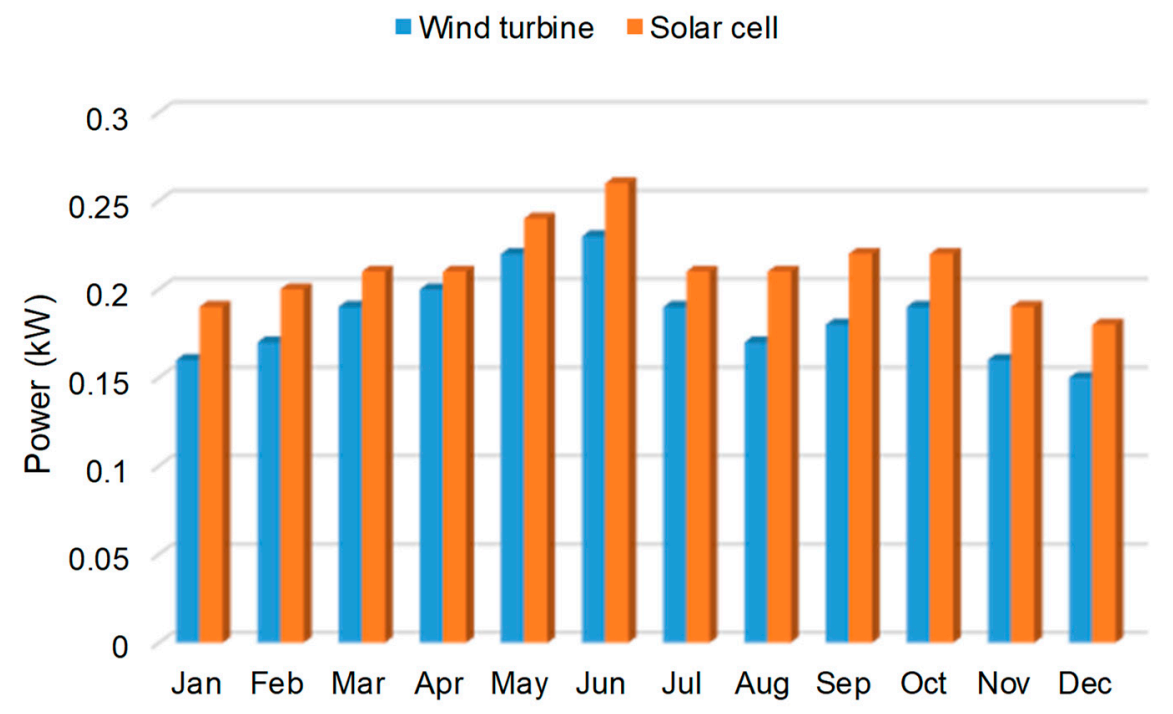

Figure 11. Comparison of electricity generation between solar PV and wind turbine at Bahawalpur.

Table 6. Comparison between Solar and wind energy in Pakistan.

\begin{tabular}{ccc}
\hline Parameters & Solar Panel (1 kWh) & Wind Energy (1 kWh) \\
\hline Price & 65,000 & 120,000 \\
Life duration & 25 Years & $10-15$ Years \\
Consumption of fuel & N/A & N/A \\
Maintenance costs & N/A & RS. 3.5/h \\
Sulfur oxide & N/A & N/A \\
\hline
\end{tabular}

\section{Grid Structure and Situation of Solar Energy in Pakistan}

Modern energy services are vital for the social and economic development of a country. Conventional energy sources are unable to meet current energy needs of Pakistan, resulting in large populations deprived of electricity. Energy requirements have increased tremendously due to advancement in technologies which have put extra pressure on grids. The traditional grid structure of Pakistan is mainly built for conventional electricity which cannot bear the current power load and does not have the ability to integrate renewable energy sources. System loss, such as distribution and transmission losses, are much higher than other South Asian countries which further exacerbate the situation. Energy shortfall cannot be fulfilled by only constructing new lines and substations. Therefore, grid infrastructure needs a major transformation to fulfill the ever-increasing electricity demand. To achieve high amount of renewable energy generation, the current grid system should convert to a smart autonomic system. Moreover, the challenges of Transmission and Distribution losses can be minimized with the introduction of smart grids [51].

Pakistan needs to deploy its intrinsic energy sources as a long-term solution to energy problems. Renewable energy sources especially solar energy has the ability to eliminate the existing energy crises of the country. Energy shortage problems can be reduced by efficiently utilizing this clean and affordable energy source [52]. Solar energy has a lot of opportunities particularly in rural areas and areas far off from national grid. Government has taken serious steps to utilize this natural asset properly in the country. AEDB has started a "solar power electricity program" to electrify rural areas. According to this program, solar systems will be installed in 100 villages of Sindh province and 400 villages of Baluchistan province. Villagers took great interest in this program and 3000 solar home solutions have been installed in Sindh province [53]. NEPRA declared a net metering policy and tariff regulations in 2015 to benefit consumers who use solar PV. A special meter has been provided to consumers which have the capability to record both in and out flow of electricity. According to this 
policy, users will be charged for their net electricity consumption. Domestic and commercial users have been inspired to install their own solar systems after the implementation of this policy. It is expected that this policy will improve the energy crises in the country [54].

\section{Solar Energy Applications in Pakistan}

\subsection{Solar PV}

In the past, the use of solar PV was only limited to individual purposes and there was no utilization of solar energy in the grid. With a growing electricity demand gap and continuous power shutdowns, government has made quick action plans to connect solar energy with the national grid. In 2010, the first solar grid plant was installed at the Planning Commission and Pakistan Engineering Council (PEC) building. The plant has total installed capacity of $178.08 \mathrm{~kW}$ which not only fulfills its own needs but can also sell surplus electricity to the Islamabad Electric Supply Company (IESCO). Similarly, the Pakistan national assembly installed a $2 \mathrm{MW}$ solar system on its building and became the world's first parliament which is completely functional on solar energy. The extra electricity of this plant is also transferred to the national grid plant [55].

With the technical assistance of the Japan International Cooperation Agency (JICA), the country built another solar energy project, with a total generating capacity of $365 \mathrm{~kW}$. Investors have taken great interest in solar energy projects after the success of the above-mentioned projects. Meanwhile, AEDB has given a Letter of Intent (LoI) to 28 companies, having total capacity of $956.52 \mathrm{MW}$. Quaid-e-Azam Solar Park is a mega project which has been constructed at Bahawalpur city with the assistance of China. It became functional in 2016 with a total capacity of $100 \mathrm{MW}$. Another three projects at the same site will become functional at the end of 2018, having a total capacity of 300 MW [46]. AEDB has given LoI to a further 17 independent power producers (IPPs) with a cumulative capacity of $484 \mathrm{MW}$. With the completion of all these projects, the installed capacity of PV available to the grid will have reached $1556 \mathrm{MW}$ in 2018. The year wise grid connected solar power capacity in Pakistan has been shown in Figure 12. Still, many solar energy projects are under construction at different locations in Pakistan as shown in Table 7 [43].

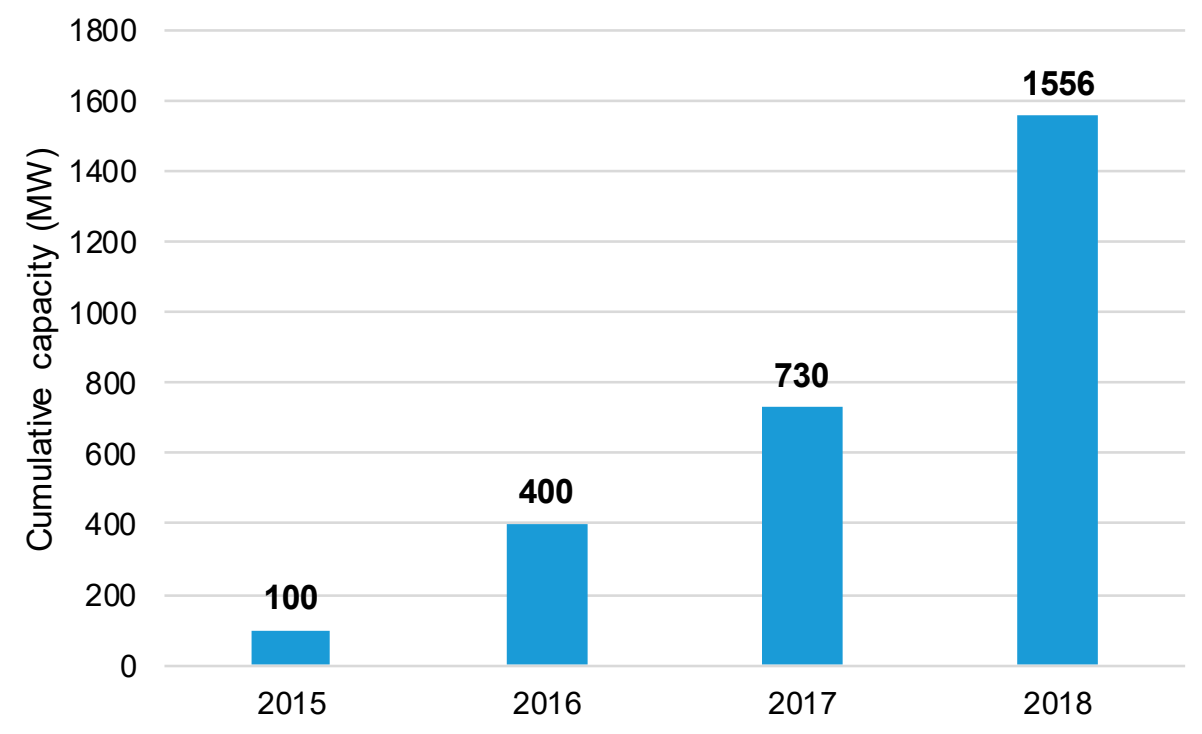

Figure 12. Year wise grid connected solar power capacity in Pakistan [43].

\subsection{Solar Thermal}

Solar thermal technology is still not fully explored in Pakistan. Solar cookers, solar water heaters and solar water pumps are potential applications on the solar thermal side. AEDB lifted a tax duty on importing different solar products, to develop solar power in the country. As a result, imports were 
increased steadily. In 2013, the government imported 14,981 solar water heaters and installed them throughout the country. Similarly, the government further imported and deployed 1429 solar water pumps to benefit the agriculture sector [56]. Solar pumps and solar water heaters were manufactured locally after 2013 and gained popularity all over the country, especially in northern areas. The winter is so cold in these mountainous areas and electricity supply is limited. Many non-government organizations (NGOs) took interest in solar cookers and distributed in northern and rural areas of Pakistan. Currently, 5000 solar cookers are in use in Pakistan.

Table 7. Under construction solar PV projects in Pakistan.

\begin{tabular}{cccc}
\hline Sr. No & Developer & Project Capacity (MW) & Location \\
\hline 1 & Asia Petroleum & 30 & Chakwal, Punjab \\
2 & First Solar Ltd. & 2 & Sindh Province \\
3 & Act Solar Ltd. & 50 & Noori Abad, Sindh \\
4 & Jafri Associates & 50 & Noori Abad, Sindh \\
5 & Solar Blue Ltd. & 50 & Punjab Province \\
6 & Adamjee Power & 10 & Thatta, Sindh \\
7 & ET Solar Ltd. & 25 & Attock, Punjab \\
8 & ET Solar Ltd. & 50 & Sialkot, Punjab \\
9 & Crystal Energy & 2 & Thatta, Sindh \\
10 & Forshine & 50 & Thatta, Sindh \\
\hline
\end{tabular}

\section{Barriers to Solar Energy Development}

Although, there is a huge potential for solar energy in Pakistan, there are certain barriers which must be overcome to utilize this technology efficiently and effectively. One of the important barriers is the high initial cost, as solar energy projects require a long time to materialize their monetary benefits. More specifically, these barriers are summarized as follows.

\subsection{Economical Barriers}

Solar energy projects are capital intensive and have low economies of scale. It requires a long time for payback.

(1) Unawareness about market potential.

(2) Initial costs are too high to start a new solar energy project.

(3) Limited government subsidies, banks are not willing to give loans for big projects.

(4) There are always risks associated with solar energy projects regarding their performance.

\subsection{Policy Barriers}

(1) Confusing policies regarding the participation of private investors.

(2) Feeble environmental structure.

(3) No feed-in tariff system.

(4) High priority to traditional sources of energy and lack of structural regulations for renewable energy.

(5) More subsidies are available for fossil fuels as compared to solar energy and other renewable technologies.

\subsection{Technological Barriers}

(1) Unreliable local technology.

(2) Local production is limited and there is no production facility of solar cells at national level.

(3) Dependence on foreign technology for key parts and equipment.

(4) Unauthentic solar maps to check the solar radiation intensity. 
(5) Dependence on foreign personnel to install and operate large solar energy projects.

\subsection{Information and Human Resource Barriers}

(1) Limited information about energy efficiency to make effective policies for mobilizing society.

(2) Limited marketing and business management skills.

(3) Limited knowledge about modern solar technology, specialized equipment, suppliers and potential financers.

(4) Lack of experts and limited human resource potential for the operation and maintenance of large solar energy projects.

(5) Limitation on collecting solar energy data and the inefficiency of project development.

\subsection{Social Barriers}

(1) Lack of awareness about solar energy especially in rural areas.

(2) Lack of social acceptance and participation. People still stick to traditional means of electricity which is a big hurdle for new solar energy projects.

(3) Some solar energy projects often come with strong opposition from local communities like the installation of solar water heaters on high roofs.

(4) If some problem suddenly occurs, residents do not have any practical knowledge about how to fix it on their own.

\section{Policy Recommendations}

The following policy recommendations are advised for Pakistani government to overcome above mentioned solar energy barriers.

(1) There is a need to educate the masses about the harms and disadvantages associated with traditional sources of energy and make them aware about the benefits related with the utilization of solar energy. This can be achieved by launching environmental awareness campaigns to highlight the importance of energy conservation and reducing greenhouse gas emissions.

(2) All stakeholders, government and NGOs should work in an integrated and coherent way to further increase the demand of solar energy in the country.

(3) To utilize solar energy properly at the domestic level, it is necessary that householders should be given subsidies and loans to purchase solar energy solutions according to their needs.

(4) Huge costs are required for the distribution and transmission networks for areas, far away from the national grid. Therefore, there is a need to develop microfinance institutions for these areas. i.e., northern mountainous areas in Gilgit Baltistan and Khyber Pakhtunkhwa, and rural areas in Sindh and Baluchistan. This task can be assigned to banks to ensure the availability of microfinance which can substantially contribute to the development of off-grid solutions.

(5) Rural dwellers and people related with agricultural professions, should be encouraged to buy solar water pumps and solar tube wells by demonstration projects at the community level. For this purpose, adequate funds should be provided for quick results.

(6) As solar energy projects are capital intensive. Only the public sector cannot cope with such huge investments. Renewable policies should be made in such a way that it should motivate both local and foreign investors to invest in solar energy projects. Incentives such as exemptions from import duties and tax reductions will be great initiatives in this regard.

(7) Policy structure should be reformed by giving more priority to renewable energy sources instead of conventional energy.

(8) Management and marketing skills should be increased to explore new markets, suppliers and modern solar technology.

(9) There is a need to cultivate local professionals from countries expert in solar energy technology. 
(10) There is a need to lessen the burden on fossil fuels by increasing the share of solar energy in total energy mix of the country. This can be achieved by adopting Feed-in Tariffs (FIT) and Renewable Portfolio Standards (RPS). These incentives will motivate power producers to invest more in solar energy projects.

(11) Local developers should be given monetary benefits, as the startup cost of new solar energy projects is very high.

(12) The government should develop a national energy research program. Ample funding should be provided for R\&D to prepare home based, energy efficient solar energy equipment. Research activities should be carried out by university students and research organizations to develop modern and cost-effective solar energy devices for residents and commercial users.

(13) Regional and international cooperation should be enhanced to transfer technology, knowledge management mechanisms, train local manpower, improve the manufacturing of key parts and to learn from each other's experiences.

\section{Conclusions}

Energy is vital for the socioeconomic progress of a country. Pakistan, like many other under developed countries solely relies1 on traditional fossil fuels to meet its energy requirements. Due to its massive population and recent industrial development, there is a huge demand for energy. Meanwhile, fossil fuel prices have increased recently, and the country has no other means to produce energy, resulting in energy short-falls. The electricity demand and supply gap has been increased tremendously. Due to the increasing energy gap, all sectors of life have been affected severely. Policy makers all over the world are looking for alternate ways of energy to solve energy scarcity problems. Different sources of alternate and renewable energy are being explored in Pakistan as well. We have compared different renewable energy sources i.e., solar and wind, based on price, average life span, emission of hazardous gases, consumption of fuel, operation and maintenance costs. We found that solar energy has emerged as a best source of renewable energy to tackle all the energy challenges as it is cheaper, does not require operation or maintenance costs and have a greater average life span than wind energy. Moreover, good wind speed is only available for 5 to 6 months of the year, while solar radiation is present all through the year in the country. Solar energy can lessen the pressure on the national budget which is being used for importing expensive fossil fuels, especially oil. The use of solar energy is only limited to solar PV, solar water heaters, solar geysers, solar cookers and solar pumps in Pakistan. Though, with the construction of the Quaid-e-Azam solar park and similar projects, the awareness of solar energy and its associated benefits have been increased among people. But until now, it's share in the total energy mix of the country is negligible. Pakistan's topography and climatic conditions are ideal for the utilization of solar energy at its maximum level. Finally, we have provided some policy implications to address the barriers in the way of solar energy, make people aware about the current energy problems of the country, by supporting and promoting solar energy practices and attract local and foreign investors to invest in solar power projects. To conclude, solar energy has the potential to solve Pakistan's energy crises in a short time period.

Author Contributions: Conceptualization, M.I.; Data curation, M.I. and M.A.; Formal analysis, M.I. and Z.-Y.Z.; Funding acquisition, Z.-Y.Z.; Writing-original draft, M.I.; Writing-review \& editing, M.A. and M.C.M..

Funding: This study was supported by "The Fundamental Research Funds for the Central Universities (2018ZD14)."

Conflicts of Interest: The authors declare no potential conflicts of interest. 


\section{Appendix A}

Table A1. List of major barriers of solar energy development and how respondents answered in semi-structured interview.

\begin{tabular}{|c|c|c|}
\hline Barriers & Items & Percentage (\%) \\
\hline \multicolumn{3}{|c|}{ Economical barriers } \\
\hline & Solar energy projects are capital intensive. & 28.9 \\
\hline & Buying solar energy system need high installation costs. & 28.4 \\
\hline & Government subsidies are limited. & 22.6 \\
\hline & Limited bank loans for solar energy projects. & 20 \\
\hline \multicolumn{3}{|c|}{ 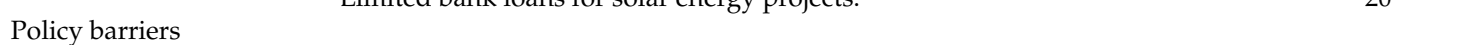 } \\
\hline & Government policies are confusing. & 38.9 \\
\hline & Solar energy projects have limited feed-in tariff. & 35.8 \\
\hline \multirow{2}{*}{\multicolumn{3}{|c|}{ Low priority for renewable energy tecnnologies. }} \\
\hline & & \\
\hline & Local technology is unreliable. & 26.6 \\
\hline & The production of solar cells is limited in the country. & 23.9 \\
\hline & There is huge dependency on foreign technology for core parts and equipment. & 24.5 \\
\hline & There is a lack of local personnel to operate large solar farms. & 25 \\
\hline \multicolumn{3}{|c|}{ Information and human resource barriers } \\
\hline & $\begin{array}{l}\text { The information regarding modern solar technology, markets and suppliers is } \\
\text { limited. }\end{array}$ & 37.4 \\
\hline & $\begin{array}{l}\text { Human resource potential is limited for the installation and maintenance of } \\
\text { solar energy projects. }\end{array}$ & 31.8 \\
\hline & Collection of solar energy data is unreliable and inefficient. & 30.8 \\
\hline \multicolumn{3}{|c|}{ Social Barriers } \\
\hline & There is unawareness of solar energy in rural areas. & 27.4 \\
\hline & Social acceptance and participation of solar energy products is limited. & 25.3 \\
\hline & This is inconvenient to install of solar water heaters on high roofs. & 24.2 \\
\hline & $\begin{array}{l}\text { Local users lack practical knowledge to fix solar energy systems, if suddenly } \\
\text { some problem occurs. }\end{array}$ & 23.2 \\
\hline
\end{tabular}

\section{References}

1. Naseem, I.; Khan, J. Impact of energy crisis on economic growth of Pakistan. Int. J. Afr. Asian Stud. 2015, 7, 33-43.

2. Fatai, K.; Oxley, L.; Scrimgeour, F.G. Modelling the causal relationship between energy consumption and GDP in New Zealand, Australia, India, Indonesia, The Philippines and Thailand. Math. Comput. Simul. 2004, 64, 431-445. [CrossRef]

3. Muneer, T.; Maubleu, S.; Asif, M. Prospects of solar water heating for textile industry in Pakistan. Renew. Sustain. Energy Rev. 2006, 10, 1-23. [CrossRef]

4. National Electric Power Regulatory Authority (NEPRA), Pakistan. State of Industry Report 2016. Available online: http:/ / www.nepra.org.pk/industryreports.htm (accessed on 10 September 2018).

5. Farooq, M.; Shakoor, A. Severe energy crises and solar thermal energy as a viable option for Pakistan. J. Renew. Sustain. Energy 2013, 5, 013104. [CrossRef]

6. Ghafoor, A.; Munir, A. Design and economics analysis of an off-grid PV system for household electrification. Renew. Sustain. Energy Rev. 2015, 42, 496-502. [CrossRef]

7. Ghafoor, A.; Rehman, T.; Munir, A.; Ahmad, M.; Iqbal, M. Current status and overview of renewable energy potential in Pakistan for continuous energy sustainability. Renew. Sustain. Energy Rev. 2016, 60, 1332-1342. [CrossRef]

8. Water and Power Development Authority (WAPDA) Home Page. Available online: http://www.wapda.gov. $\mathrm{pk} /$ (accessed on 12 September 2018).

9. Wakeel, M.; Chen, B.; Jahangir, S. Overview of energy portfolio in Pakistan. Energy Procedia 2016, 88, 71-75. [CrossRef]

10. Ahmed, S.; Mahmood, A.; Hasan, A.; Sidhu, G.A.S.; Butt, M.F.U. A comparative review of China, India and Pakistan renewable energy sectors and sharing opportunities. Renew. Sustain. Energy Rev. 2016, 57, $216-225$. [CrossRef]

11. Sharma, A.; Srivastava, J.; Kar, S.K.; Kumar, A. Wind energy status in India: A short review. Renew. Sustain. Energy Rev. 2012, 16, 1157-1164. [CrossRef] 
12. Hameed, N. Solutions for Energy Crises in Pakistan. Islamabad Policy Research Institute (IPRI), 2015; Volume II. Available online: http:/ / www.ipripak.org/wp-content/uploads/2016/01/sfecpii.pdf (accessed on 15 September 2018).

13. International Energy Agency (IEA). World Energy Statistics Report 2018. Available online: https://www.iea. org/ (accessed on 20 September 2018).

14. Luckow, P.; Fagan, B.; Fields, S.; Whited, M. Technical and Institutional Barriers to The Expansion of Wind and Solar Energy; Synapse: Cambridge, MA, USA, 2015; Available online: http:/ /www.synapse-energy.com/ sites / default/files / Barriers-to-Wind-and-Solar-15-047_0.pdf (accessed on 21 September 2018).

15. Palz, W.; Caratti, G.; Zervos, A. Renewable energy development in Europe. Int. J. Sol. Energy 1994, 15, 1-23. [CrossRef]

16. Bakhtiar, F.; Ahmed, A. A Review of Solar Energy in Pakistan: Current Status and Future Prospects. Science 2017, 36, 189-195.

17. Sheikh, M.A. Energy and renewable energy scenario of Pakistan. Renew. Sustain. Energy Rev. 2010, 14, 354-363. [CrossRef]

18. Khalil, B.H.; Zaidi, S.J.H. Energy crisis and potential of solar energy in Pakistan. Renew. Sustain. Energy Rev. 2014, 31, 194-201. [CrossRef]

19. Shaikh, P.H.; Shaikh, F.; Mirani, M. Solar energy: Topographical asset for Pakistan. Appl. Sol. Energy 2013, 49, 49-53. [CrossRef]

20. Farooq, M.K.; Kumar, S. An assessment of renewable energy potential for electricity generation in Pakistan. Renew. Sustain. Energy Rev. 2013, 20, 240-254. [CrossRef]

21. Shakeel, S.R.; Takala, J.; Shakeel, W. Renewable energy sources in power generation in Pakistan. Renew. Sustain. Energy Rev. 2016, 64, 421-434. [CrossRef]

22. Mirza, U.K.; Maroto-Valer, M.M.; Ahmad, N. Status and outlook of solar energy use in Pakistan. Renew. Sustain. Energy Rev. 2003, 7, 501-514. [CrossRef]

23. Bhutto, A.W.; Bazmi, A.A.; Zahedi, G. Greener energy: Issues and challenges for Pakistan-Solar energy prospective. Renew. Sustain. Energy Rev. 2012, 16, 2762-2780. [CrossRef]

24. Mirza, U.K.; Ahmad, N.; Majeed, T.; Harijan, K. Wind energy development in Pakistan. Renew. Sustain. Energy Rev. 2007, 11, 2179-2190. [CrossRef]

25. Hassan, M.; Afridi, M.K.; Khan, M.I. An overview of alternative and renewable energy governance, barriers, and opportunities in Pakistan. Energy Environ. 2018, 29, 184-203. [CrossRef]

26. Aziz, M.F.; Abdulaziz, N. Prospects and challenges of renewable energy in Pakistan. In Proceedings of the 2010 IEEE International Energy Conference and Exhibition (Energy Con), Manama, Bahrain, 18-22 December 2010.

27. Khattak, N.; Hassnain, S.R.; Shah, S.W.; Mutlib, A. Identification and removal of barriers for renewable energy technologies in Pakistan. In Proceedings of the 2006 2nd International Conference on Emerging Technologies (ICET'06), Peshawar, Pakistan, 13-14 November 2006; Available online: https: / / ieeexplore. ieee.org/abstract/document/4136951/ (accessed on 15 October 2018).

28. Raza, W.; Saulat, H.; Shams, U.I.; Maryam, A. Renewable energy resources current status and barriers in their adaptation for Pakistan. J. Bioprocess Chem. Eng. 2015, 3, 1-9.

29. Renewable Policy Network for the 21st Century. Renewables 2018 Global Status Report. Available online: http:/ / www.ren21.net/wp-content/uploads/2018/06/17-8652_GSR2018_FullReport_web_final_ .pdf (accessed on 23 September 2018).

30. Hydrocarbon Development Institute of Pakistan (HDIP). Pakistan energy yearbook Report 2015-2016. Available online: https: / /www.hdip.com.pk (accessed on 15 October 2018).

31. Central Electricity Authority (CEA). Executive Summary Report Aug-2018. Available online: http:/ / www. cea.nic.in/reports/monthly/executivesummary/2018/exe_summary-08.pdf (accessed on 15 October 2018).

32. Energy Information Administration (EIA). Today in Energy. Available online: https:/ / www.eia.gov (accessed on 15 October 2018).

33. International Renewable Energy Agency (IRENA). Renewable Capacity Statistics Report 2018. Available online: https://www.irena.org/-/media/Files/IRENA/Agency/Publication/2018/Mar/IRENA_RE_ Capacity_Statistics_2018.pdf (accessed on 15 October 2018).

34. Encyclopedia Britannica Home Page. Available online: https://www.britannica.com/place/Punjabprovince-Pakistan (accessed on 25 September 2018). 
35. Library of Congress Home Page. Available online: https:/ /www.loc.gov/ (accessed on 26 September 2018).

36. Worlodometers Home Page. Available online: http://www.worldometers.info/world-population/pakistanpopulation/ (accessed on 27 September 2018).

37. The World Bank Home Page. Available online: https://data.worldbank.org/country/pakistan (accessed on 27 September 2018).

38. Sharma, S.; Kishan, R.; Doig, A. Low Carbon Development in South Asia: Leapfrogging to a Green Future Report. Climate Action Network South Asia, 2014. Available online: http:/ / www.cansouthasia.net/pdf_ files/Low\%20Carbon\%20Development\%20in\%20South\%20Asia.pdf (accessed on 6 October 2018).

39. Javed, M.S.; Raza, R.; Hassan, I.; Saeed, R.; Shaheen, N.; Iqbal, J.; Shaukat, S.F. The energy crisis in Pakistan: A possible solution via biomass-based waste. J. Renew. Sustain. Energy 2016, 8, 043102. [CrossRef]

40. Malik, A. Power Crisis in Pakistan: A Crisis in Governance? Pakistan Institute of Development Economics: Islamabad, Pakistan, 2012.

41. International Energy Agency (IEA). Energy Access Outlook from Poverty to Prosperity Report 2017. Available online: https://www.iea.org/publications/freepublications/publication/WEO2017SpecialReport_ EnergyAccessOutlook.pdf (accessed on 10 October 2018).

42. Kamran, M. Current status and future success of renewable energy in Pakistan. Renew. Sustain. Energy Rev. 2018, 82, 609-617. [CrossRef]

43. Alternative Energy Development Board (AEDB). Ministry of Water and Power, Government of Pakistan. Available online: http:/ / www.aedb.org/ (accessed on 15 October 2018).

44. Energy Sector Management Assistance Program. Renewable Energy Resource Mapping in Pakistan. Available online: http:/ / esmap.org/re_mapping_pakistan (accessed on 18 October 2018).

45. Jatoi, L. Policy for Development of Renewable Energy for Power Generation: Government of Pakistan; Alternative Energy Development Board Pakistan: Islamabad, Pakistan, 2006.

46. Iftikhar, M.; Najeeb, F.; Mohazzam, S.; Khan, S. Sustainable Energy for All in South Asia Potential, Challenges, and Solutions; IDEAS: Islamabad, Pakistan, 2017; Available online: https:/ /ideas.repec.org/p/ess/wpaper/ id12275.html (accessed on 10 October 2018).

47. Sheikh, M.A. Renewable energy resource potential in Pakistan. Renew. Sustain. Energy Rev. 2009, 13, 2696-2702. [CrossRef]

48. Mehmood, A.; Waqas, A.; Mahmood, H.T. Stand-alone PV system assessment for major cities of Pakistan based on simulated results: A comparative study. NUST J. Eng. Sci. 2013, 6, 33-37.

49. Alternative Energy Development Board (AEDB). Ministry of Energy, Power Division, Government of Pakistan. Available online: http:/ / www.aedb.org/component/judownload/root/2-wind/8-wind-mapof-pakistan?Itemid=101 (accessed on 15 October 2018).

50. Government of Pakistan Ministry of Finance. Pakistan Economic Survey 2015-2016. Available online: http:/ / www.finance.gov.pk/survey_1516.html (accessed on 28 October 2018).

51. Nayyar, Z.A.; Zaigham, N.A. Satellite image identification of wind channels to delineate wind energy generation sites in Pakistan. J. Basic Appl. Sci. 2014, 10, 344-348. [CrossRef]

52. Sustainable Development Policy Institute (SDPI), Pakistan. Pakistan Energy Vision 2035, Executive Summary. Available online: https:/ /sdpi.org/publications/publication_details-624-8.html (accessed on 10 September 2018).

53. Government of Pakistan Ministry of Finance. Pakistan Economic Survey 2010-2011. Available online: http:/ / www.finance.gov.pk/survey/chapter_11/15-Energy.pdf (accessed on 28 October 2018).

54. National Electric Power Regulatory Authority (NEPRA), Pakistan. NEPRA KK to Promote Power Generation by Consumers. Available online: http:/ / www.dawn.com/news/1204847 (accessed on 12 September 2018).

55. National Assembly of Pakistan. Pakistan's Parliament Goes Green. Available online: http://www.na.gov.pk (accessed on 27 October 2018).

56. Government of Pakistan Ministry of Finance. Pakistan Economic Survey 2012-2013. Available online: http:/ / www.finance.gov.pk/survey_1213.html (accessed on 29 October 2018).

(C) 2019 by the authors. Licensee MDPI, Basel, Switzerland. This article is an open access article distributed under the terms and conditions of the Creative Commons Attribution (CC BY) license (http://creativecommons.org/licenses/by/4.0/). 